\title{
Phytosociology of a natural fragment of the floodplain forest in the Lower Tapajós River, Brazil
}

\author{
Fitosociología de un fragmento natural de bosque inundable en el Bajo Río Tapajós, Brasil
}

\author{
Diego dos Santos Vieira ${ }^{\text {a*, }}$ Marcio Leles Romarco de Oliveira a , João Ricardo Vasconcelos Gama ${ }^{\text {b }}$ \\ Evandro Luiz Mendonça Machado a, Eric Bastos Görgens a, Bruno Oliveira Lafetá a, Josinei Silva Garcia ${ }^{\text {b }}$ \\ *Autor de correspondência: ${ }^{\text {a }}$ Federal University of Jequitinhonha and Mucuri Valleys, \\ Department of Forestry, Diamantina, Brazil, tel.: 55-93-991973755, diegovieir4@gmail.com. \\ ${ }^{\mathrm{b}}$ Federal University of Para West, Department of Forestry, Santarém, Brazil.
}

\begin{abstract}
SUMMARY
The aim of this study was to describe the floristic, structure and spatial pattern of species occurring in a natural fragment of the floodplain forest in the lower Tapajós River, Pará. Three hundred and eight contiguous sampling unities of $100 \mathrm{~m}^{2}$ were installed, comprising a sampling area of 3.08 ha. In each plot, all individuals with DBH (diameter at breast height of $1.30 \mathrm{~cm}$ ) equal to or higher than $10 \mathrm{~cm}$ were measured, identified, and referenced in Cartesian coordinates (X, Y). The analyses of the diversity and spatial pattern were performed using the Shannon-Weaver index and the Ripley's K function, respectively. There were 1,022 individuals surveyed, including 64 tree species and 33 families. The diversity recorded was 3.03; the total density was determined to be 331.8 individuals ha-1 and basal area of $16.10 \mathrm{~m}^{2} \mathrm{ha}^{-1}$. The species of high ecological value were Campsiandra laurifolia, Hevea brasiliensis, Glicoxylon pedicellatum, Tetragastris altissima, Vantanea parviflora and Mabea caudata. The diametric distribution of the community and species, except for Hevea brasiliensis, behaved as expected for uneven-aged forests, and presented an exponential distribution with an inverted $\mathbf{J}$ form. The community spatial pattern showed variations depending on the considered distance, however there was a predominance of aggregated distribution. The spatial patterns detected on the species were: I - partially aggregated and random for Vantanea parviflora species, II - completely aggregated to the Hevea brasiliensis and Glicoxylon pedicellatum species, and III predominantly aggregated to Campsiandra laurifolia, Tetragastris altissima and Mabea caudata.
\end{abstract}

Key words: vertical structure, Ripley’s K function, Amazon, floristic diversity.

\section{RESUMEN}

El objetivo de este estudio fue describir la flora, estructura y distribución espacial de las especies que se producen en un fragmento natural de bosque inundable en el Bajo Río Tapajós, Pará. Se instalaron 308 unidades de muestreo contiguos de $100 \mathrm{~m}^{2}$, que comprende un área de muestreo de 3,08 ha. En cada parcela, todos los individuos con diámetro a 1,30 cm del suelo superior o igual a $10 \mathrm{~cm}$ fueron medidos, identificados y referenciados en coordenadas cartesianas (X,Y). El análisis de la diversidad y el patrón espacial se realizó mediante el índice de Shannon-Weaver y la función K de Ripley, respectivamente. Se inventariaron 1.022 individuos, distribuidas en 64 especies y 33 familias. La diversidad registrada fue de 3,03, la densidad total de 331,8 individuos ha ${ }^{-1}$ y el área basal de 16,10 $\mathrm{m}^{2} \mathrm{ha}^{-1}$. Las especies de mayor importancia ecológica fueron Campsiandra laurifolia, Hevea brasiliensis, Glicoxylon pedicellatum, Tetragastris altissima, Vantanea parviflora y Mabea caudata. La distribución del diámetro para la comunidad y las especies, excepto la Hevea brasiliensis, se comportó como se espera para bosques multietáneos, es decir, distribución exponencial en forma de J-invertida. El patrón espacial de la comunidad mostró variaciones en función de la distancia, sin embargo, hubo predominio de la distribución agregada. Los patrones espaciales de las especies encontradas fueron: I) agregado parcialmente y aleatorio de la especie Vantanea parviflora; II) agregado por completo de las especies Hevea brasiliensis y Glicoxylon pedicellatum; y III) predominantemente agregado para Campsiandra laurifolia, Tetragastris altissima y Mabea caudata.

Palabras clave: estructura vertical, K de Ripley, Amazon, diversidad florística.

\section{INTRODUCTION}

The complex set of vegetation types that make up the Amazon biome is the expression of multiple conditioning variables as geological origin, lay of the land, adjacent vegetation and climatic factors, which are of inestimable im- portance to local biodiversity maintenance and quality of water resources. An integral part of these crop formations, the Alluvial Dense Rainforests, commonly called "riparian forests and riverside forests," mainly constitute environments located on the banks of some rivers and humid lowlands that are influenced by seasonal flooding, which 
consequently causes the fragmentation of the natural habitats (IBGE 2012) by exclusive species selectivity.

Due to the intensity and frequency of floods, gradual changes in water flows and the dynamics of removal and deposition of sediments, these biotic communities are prone to constant instability and reorganization, since their establishment processes, growth and reproduction are influenced by water levels. Although they are considered permanent preservation areas by Federal Law $\mathrm{N}^{\circ}$ 12651/2012 of the Brazilian Forest Code, riparian forests are among the most threatened ecosystems, because they are complex and fragile systems that face continuous anthropogenic impacts. According to Freitas et al. (2013) and Dias et al. (2014) many of these areas, essential for the maintenance and protection of water resources, serve as vegetation corridors that, among other benefits, increase the transit of pollinators and seed dispersers and the possibility of genetic exchange with remote areas.

Despite the environmental benefits of maintaining these ecosystems and that the risks of destruction are well known, efforts for the conservation of these areas normally encounter not very comfortable situations, since besides the increase of illegal deforestation rates in the Amazon, much has been discussed about the construction of a hydroelectric dam complex on the Tapajós River, which may, among other environmental impacts, cause loss of native vegetation and decrease of local biodiversity. However, when pursuing to characterize and circumscribe the tree species in floodplains through floristic surveys, there is a better understanding of the dynamics leading intraspecific relationships of vegetation and its relations with the abiotic environment, in order to contribute to a better conservation or recovery of these ecosystems. Chaves and Manfredi (2010), for example, identified by means of a floristic survey 22 species with medicinal potential, which can be used in the recovery of riparian forests, while Gomes et al. (2014) and Ferreira et al. (2010) observed that the species of the Fabaceae family are the most occurring in riparian forests, which means that species of this family should be prioritized in projects for the recovery and restoration of these ecosystems.

Several phytosociological studies have been reported in the Amazon, but there are only a few forest inventories that have been carried out in floodplains, mostly concentrated near Manaus (AM) and Belém (PA) (Parolin et al. 2004, Hamaguchi and Scudeller 2011). Others have been conducted on the Xingu River and Jaú National Park (Ferreira 1997). Considering the environmental benefits, as well as the lack of information on floodplain forests in the western Pará, phytosociological surveys describing structural and spatial aspects of vegetation become essential. In addition, the available scientific knowledge claims that activities related to conservation, management and restoration of floodplain formations are not susceptible to generalizations, therefore the diversity of species as the producers of ecological restoration projects on such formations must be out of date.
Generally, these projects should be based on studies carried out on the remains of floodplain forests of the region, to support the selection of characteristic species of this formation, considering spatial distribution aspects of species, their adaptability to different environments and ecological groups, ensuring a successful restoration (Rodrigues and Naves 2000). Whereas wetland areas present exclusive species of these environments, this study aims at determining the floristic, structural and spatial aspects of tree species in an area of Alluvial Dense Rainforests in the western Pará, to support forest conservation and restoration plans in the Tapajós River. The hypotheses are: the area has low floristic diversity; the exclusive species are dominant and distributed in aggregate form; the spatial pattern prevalent is the aggregate.

\section{METHODS}

Study area. The study was conducted in the Amazonian Peace Island, within the Tapajós National Forest domains. This is an excerpt of the periodically floodplain forests, belonging to the community of Jamaraquá, located in the geographic coordinate $2^{\circ} 49^{\prime} 07.24^{\prime \prime} \mathrm{S}$ and $55^{\circ} 02^{\prime} 13.52^{\prime \prime} \mathrm{W}$ on the right bank of the Tapajós River. According to the local community information, the area has suffered severe disruptions since 2003 because of the irregular flooding pulse of the Tapajós River in the last years, which reached up to $8.32 \mathrm{~m}$. The climate of the region, according to Köppen system, is classified as Ami, that is humid tropical climate with an annual temperature variations of less than 5 ${ }^{\circ} \mathrm{C}$ and the average annual temperature is $25.5^{\circ} \mathrm{C}$, average relative humidity of the air is $88 \%$ and average annual rainfall is $1,820 \mathrm{~mm}$. According to the classification of the Brazilian Institute of Geography and Statistics - IBGE (2012) the area is considered Alluvial Rainforest, with a flood period from December to June, while the low water period occurs between July and November.

Data collection. The community was delimited in an area of 3.08 ha, subdivided into 308 contiguous plots of 100 $\mathrm{m}^{2}(10 \times 10 \mathrm{~m})$, covering as much of the flooded area as possible. In each plot, all individuals with DBH (diameter at breast height of $1.30 \mathrm{~m}$ ) equal to or higher than 10 $\mathrm{cm}$ were measured, identified, and referenced in Cartesian coordinates $(\mathrm{X}, \mathrm{Y})$. The arboreal individuals that met the inclusion criteria and presented bifurcations below $1.30 \mathrm{~m}$ were evaluated as a single individual. In such cases, after the registration of the diameters of each branch the quadratic diameter formula [1] was used to determine the overall diameter of the individual. The quadratic diameter of a tree with $n$ branches was obtained by the following expression:

$$
d=\sqrt{d_{1}^{2}+d_{2}^{2}+d_{3}^{2}+\ldots+d_{n}^{2}}
$$

Where: $d=$ quadratic diameter $(\mathrm{cm})$ and $d_{i} \cdots_{n}=$ diameter of each branch. 
The trees were previously identified in the field by species, and those which raised doubts had their taxonomic determination ascertained by experts, through comparisons, in the herbarium of the Federal University of Western Pará. The classification of species followed the Angiosperm Phylogeny Group III system (2009).

Floristic composition and diversity. The floristic composition was analyzed based on the distribution of individuals in species and families. Shannon-Weaver diversity index [2] and Pielou's evenness index [3] were calculated as indicators of diversity and floristic heterogeneity (Brower $e t$ al. 1998). Pielou's evenness index allowed representing the uniformity of distribution of individuals among all existing species, reaching values of 0 (zero) to 1 (one).

$$
\begin{gathered}
H^{\prime}=-\sum_{i=1}^{S} p_{i} \cdot \ln \left(p_{i}\right) \quad p_{i}=\frac{n_{i}}{N} \\
\mathrm{~J}=\frac{\mathrm{H}^{\prime}}{\mathrm{H}_{\text {max }}^{\prime}} \quad \mathrm{H}_{\text {max }}^{\prime}=\ln (\mathrm{s})
\end{gathered}
$$

Where: = Shannon-Weaver diversity index, $J=$ Pielou's evenness index, $=$ maximum sampled diversity, $n_{i}=$ number of sampled individuals of the ith species, $N=$ total number of sampled individuals, $S=$ total number of sampled species.

Forest structure. In the structural analysis the following parameters were considered for each species, as recommended by Mueller-Dombois and Ellenberg (1974): absolute density and relative density; absolute dominance and relative dominance; absolute frequency and relative frequency; absolute sociological position and relative sociological position. Similarly, the ecological importance of the species in the ecosystem was estimated from the expanded importance value index. A stratification of community heights was performed using multivariate analysis techniques. The trees were arranged in ascending order of their total height, classified by an amplitude of $1 \mathrm{~m}$, and subsequently developed an $\mathrm{X}$ matrix of total height data. Each variable $x_{\mathrm{ij}}$ represented the total height providing the $i$ th tree classified to $j$ th class height. The $\mathrm{X}$ matrix is the input for the cluster and discriminant analysis. The Euclidean distance and Ward's method were used, through the expressions [4] and [5] (Souza et al. 2003):

$$
\begin{gathered}
d_{i j}=\sqrt{\sum_{h=1}^{p}\left(x_{h i}-x_{h j}\right)^{2}} \quad h=1,2, \ldots, P \\
d_{i j}^{2}=\left(x_{i}-x_{j}\right)^{2}
\end{gathered}
$$

Where: $=$ Euclidean distance estimated between $i$ and $j,=$ diameter of the $i$ th class in the $i$ th diameter class, $=$ dia- meter of the $i$ th class at $j$ th diameter class, and $=$ distance between the mean of groups $I$ and $J$.

The discriminant analysis was used to confirm the distinction and classification of height classes obtained by a cluster analysis (Souza et al. 2003). The diametric structure of the community and of the species of high ecological value was obtained by the calculation of the individuals of each species within the diametric class to which they belong. The diameter classes were established with amplitude of $10 \mathrm{~cm}$, starting in the minimum diameter of the inclusion of individuals.

Spatial pattern. The spatial pattern was defined by Ripley' $K(s)$ function, which considers the variation of all distances among all events (Ripley 1979). In a simplified way, a circle of $s$ radius centered on each tree was defined, where the number of neighbors present in the area of this circle was counted. Varying the $s$ radius the spatial pattern of the species was detected at different distance scales. However, particular cases occurred when the trees were close to the edge of the area, since the $K(s)$ function is accumulative and computes all distances among all points, trees near the $s$ radius edge that were larger than the map boundary could not be interpreted as if there were no neighbors. Neighbors existed there, but because they are outside the boundaries of the area they were not counted. Therefore, the number of neighboring trees to nearby trees in the map limits would be lower than others, causing a bias in the calculation on the $K(s)$ function estimator. Hence, we used the estimator of the $K(s)$ function with the isotropic edge correction proposed by Ripley (1979) [6].

$$
\hat{K}(s)=\frac{1}{\hat{\lambda}_{n}} \sum_{i=1}^{n} \sum_{i=1}^{n} W_{I}^{-1}\left(X_{i}, X_{j}\right) I\left(\left\|X_{i}-X_{j}\right\| \leq s\right), \text { para } i \neq j \quad \text { e } s>0
$$

Where: $n=$ number of trees in the study area, $x_{i}$ e $x_{j}=$ coordinates of the places in the map, Euclidian distance among localizations $x_{i}$ and $x_{i}, s=$ arbitrary distance vector, $=\mathrm{n} /=$ number of trees divided by the area of the study area, being a neutral estimator of the process intensity, $\mathrm{W}_{\mathrm{I}}\left(x_{i}, x_{j}\right)=$ isotropic edge correction function, which represents a portion of the circumference with center $x_{i}$ and with radio that is out for any convex polygon, $\mathrm{I}(\mathrm{U})=$ indicator function that takes the value 1 whenever the $U$ condition is true and zero as false.

The maximum distance that was studied was $110 \mathrm{~m}$, since this is the approximate half of the higher longitudinal axis of the area, while the $s$ radius was set at $5 \mathrm{~m}$. This way, the Ripley's $K(s)$ function evaluated the relationship between pair events every $5 \mathrm{~m}$ to a maximum depth of $1,500 \mathrm{~m}$. To analyze the data graphically, a confidence graphic scale was built through 500 Monte Carlo simulations, performed by Complete Spatial Randomness Model (CSR). Afterward, we calculated the $K(s)$ function for the 
simulation results, by storing the minimum and maximum values of the estimate of $K(s)$, used to generate confidence intervals to $99 \%$ probability.

To facilitate the analysis, values of the $K(s)$ function were transformed to $L(\mathrm{~s})$ [7] and distributed graphically, where the axes of abscissas and ordinates represent the accumulated $s$ distance and the transformed values of $K(s)$ function, respectively (Ripley 1979).

$$
\hat{L}(s)=\sqrt{\frac{\hat{K}(s)}{\pi}}-s
$$

As a result, we obtained a confidence graphic scale identified by two dotted boundary lines, one positive and one negative. If the observed values of $L(s)$ are within the elaborated scale, the spatial pattern is random, otherwise the null hypothesis is rejected and it is assumed that the spatial pattern of individuals is added when passing the scale upper limit; and it is regular, when passing the lower limit (Ripley 1979). Calculations were performed using the $\mathrm{R}$ software 3.1.2 version, and the $K(s)$ function was estimated by Splancs package.

\section{RESULTS}

Floristic composition, structure and diversity. A total of 1,022 individuals were recorded, distributed in 58 genera, 33 botanical families and 64 tree species (table 1). The estimated absolute density was 331.8 individuals ha $^{-1}$, basal area of $16.10 \mathrm{~m}^{2} \mathrm{ha}^{-1}$ and a mean diameter of $24.8 \mathrm{~cm}$. The botanical families with the largest number of individuals were: Fabaceae (437 individuals), Euphorbiaceae

Table 1. Phytosociological parameters of the species sampled in a natural fragment of floodplain forest in the lower Tapajós River, State of Pará, Brazil.

Parámetros fitossociológicos de las especies muestreadas en un fragmento de bosque natural inundable en el bajo río Tapajós, estado de Pará, Brasil.

\begin{tabular}{|c|c|c|c|c|c|c|}
\hline Species & Families & $\mathrm{AF}$ & $\mathrm{AD}$ & ADo & ASP & EIV \\
\hline Campsiandra laurifolia Benth. & Fabaceae & 15.58 & 92.53 & 1.94 & 60.99 & 20.59 \\
\hline Hevea brasiliensis (Willd. ex A.Juss.) Müll.Arg. & Euphorbiaceae & 18.18 & 23.38 & 3.36 & 6.74 & 10.49 \\
\hline Glicoxylon pedicellatum Ducke & Sapotaceae & 8.77 & 25.65 & 1.22 & 12.59 & 6.81 \\
\hline Tetragastris altissima (Aubl.) Swart & Burseraceae & 16.56 & 20.45 & 0.78 & 10.94 & 6.62 \\
\hline Vantanea parviflora Lam. & Humiriaceae & 11.04 & 17.86 & 0.70 & 10.09 & 5.39 \\
\hline Mabea caudata Pax et K.Hoffm. & Euphorbiaceae & 9.09 & 17.86 & 0.32 & 12.15 & 4.81 \\
\hline Inga capitata Desv. & Fabaceae & 5.19 & 9.74 & 0.86 & 4.31 & 3.40 \\
\hline Swartzia sp. & Fabaceae & 7.14 & 10.71 & 0.33 & 6.34 & 3.21 \\
\hline Inga auristellae Harms & Fabaceae & 4.87 & 9.09 & 0.53 & 3.80 & 2.72 \\
\hline Myrciaria floribunda O.Berg & Myrtaceae & 7.14 & 7.47 & 0.15 & 3.77 & 2.33 \\
\hline Nectandra cuspidata Nees et Mart. & Lauraceae & 4.87 & 5.19 & 0.52 & 2.26 & 2.21 \\
\hline Vataireopsis speciosa Ducke & Fabaceae & 2.92 & 3.57 & 0.74 & 1.21 & 2.00 \\
\hline Couepia hoffmaniana $\mathrm{Kl}$. & Chrysobalanaceae & 1.95 & 7.79 & 0.23 & 5.09 & 1.92 \\
\hline Pera glabrata (Schott) Poepp. ex Müll.Arg. & Peraceae & 2.92 & 6.49 & 0.11 & 4.47 & 1.69 \\
\hline Guarea guidonia $($ L.) Sleumer & Meliaceae & 3.90 & 4.87 & 0.16 & 3.35 & 1.64 \\
\hline Coccoloba latifolia Lam. & Polygonaceae & 3.57 & 7.47 & 0.12 & 2.68 & 1.63 \\
\hline Brosimum guianensis (Aubl.) Huber & Moraceae & 3.57 & 4.87 & 0.25 & 2.40 & 1.59 \\
\hline Crudia pubescens Spruce & Fabaceae & 2.60 & 4.22 & 0.37 & 2.29 & 1.58 \\
\hline Licania kunthiana Hook.f. & Chrysobalanaceae & 3.25 & 3.25 & 0.27 & 1.34 & 1.31 \\
\hline Sideroxylon obtusifolium (Roem. et Schult.) T.D.Penn. & Sapotaceae & 1.62 & 2.27 & 0.39 & 0.46 & 1.07 \\
\hline Dialium guianense (Aubl.) Sandwith. & Fabaceae & 2.27 & 2.27 & 0.33 & 0.39 & 1.06 \\
\hline Conepia robusta Huber & Chrysobalanaceae & 2.60 & 2.60 & 0.14 & 1.51 & 0.99 \\
\hline Dipteryx polyphylla Huber & Fabaceae & 1.62 & 1.62 & 0.31 & 0.70 & 0.94 \\
\hline Duroia fusifera Hook.f. ex K.Schum. & Rubiaceae & 2.60 & 2.92 & 0.04 & 2.01 & 0.93 \\
\hline
\end{tabular}


Table 1 Continued

\begin{tabular}{|c|c|c|c|c|c|c|}
\hline Roupala brasiliensis Klotzsch & Proteaceae & 1.30 & 2.92 & 0.14 & 2.01 & 0.90 \\
\hline Tapirira guianensis Aubl. & Anacardiaceae & 1.95 & 2.60 & 0.19 & 0.61 & 0.85 \\
\hline Byrsonima stipulaceae A. Juss. & Malpighiaceae & 1.62 & 1.95 & 0.09 & 0.93 & 0.64 \\
\hline Sloanea dentata L. & Elaeorcapaceae & 1.30 & 1.62 & 0.07 & 1.12 & 0.56 \\
\hline Himatanthus sucuuba (Spruce) Woodson & Apocynaceae & 1.62 & 1.62 & 0.06 & 0.71 & 0.54 \\
\hline Simarouba amara Aubl. & Simaroubaceae & 1.62 & 1.62 & 0.05 & 0.71 & 0.54 \\
\hline Ormosia nobilis Tul. & Fabaceae & 0.32 & 0.97 & 0.20 & 0.67 & 0.53 \\
\hline Qualea cassiquiarensis Spruce ex Warm. & Vochysiaceae & 0.97 & 1.30 & 0.11 & 0.76 & 0.51 \\
\hline Lonchocarpus spruceanus Benth. & Fabacea & 0.97 & 1.95 & 0.03 & 1.20 & 0.50 \\
\hline Copaifera martii Hayne & Fabaceae & 1.30 & 1.30 & 0.10 & 0.48 & 0.50 \\
\hline Eschweilera grandiflora (Aubl.) Sandwith & Lecythidaceae & 0.97 & 0.97 & 0.10 & 0.40 & 0.43 \\
\hline Anacardium spruceanum Benth. ex Engl. & Anacardiaceae & 0.97 & 1.30 & 0.03 & 0.89 & 0.41 \\
\hline Enterolobium schomburgkii Benth. & Fabaceae & 0.97 & 0.97 & 0.06 & 0.40 & 0.36 \\
\hline Casearia grandiflora Cambess. & Salicaceae & 0.97 & 0.97 & 0.04 & 0.67 & 0.36 \\
\hline Diplotropis leptophylla Kleinhoonte & Fabaceae & 0.97 & 0.97 & 0.06 & 0.32 & 0.35 \\
\hline Arrabidaea chica (Humb. et Bonpl.) B.Verl. & Bignoniaceae & 0.97 & 0.97 & 0.01 & 0.67 & 0.32 \\
\hline Caryocar glabrum Pers. & Caryocaraceae & 0.65 & 0.65 & 0.09 & 0.24 & 0.32 \\
\hline Naucleopsis glabra Spruce ex Pittier & Moraceae & 0.97 & 0.97 & 0.04 & 0.26 & 0.31 \\
\hline Myrcia bracteata DC. & Myrtaceae & 0.97 & 0.97 & 0.03 & 0.40 & 0.31 \\
\hline Iryanthera juruensis Warb. & Myristicaceae & 0.97 & 0.97 & 0.01 & 0.53 & 0.30 \\
\hline Rheedia acuminata Planch. et Triana & Clusiaceae & 0.97 & 0.97 & 0.01 & 0.53 & 0.30 \\
\hline Licania heteromorpha Benth. & Chrysobalanaceae & 0.65 & 0.65 & 0.06 & 0.45 & 0.30 \\
\hline Crataeva benthamii Eichler & Capparaceae & 0.65 & 0.97 & 0.01 & 0.67 & 0.28 \\
\hline Rapanea ferruginea (Ruiz et Pav.) Mez & Primulaceae & 0.65 & 0.65 & 0.05 & 0.31 & 0.27 \\
\hline Derris spruceana (Benth.) Ducke & Fabaceae & 0.65 & 0.65 & 0.02 & 0.45 & 0.24 \\
\hline Myrcia acuminata DC. & Myrtaceae & 0.65 & 0.65 & 0.01 & 0.45 & 0.22 \\
\hline Inga heterophylla Willd. & Fabaceae & 0.65 & 0.65 & 0.01 & 0.45 & 0.22 \\
\hline Genipa americana L. & Rubiaceae & 0.65 & 0.65 & 0.01 & 0.45 & 0.21 \\
\hline Duguetia sp. & Annonaceae & 0.65 & 0.65 & 0.02 & 0.17 & 0.19 \\
\hline Astrocaryum aculeatum Hort ex H.Wendl. & Arecaceaea & 0.32 & 0.32 & 0.03 & 0.22 & 0.15 \\
\hline Swartzia laurifolia Benth. & Fabaceae & 0.32 & 0.32 & 0.03 & 0.09 & 0.14 \\
\hline Vismia baccifera Reichardt & Clusiaceae & 0.32 & 0.32 & 0.03 & 0.09 & 0.13 \\
\hline Simaba trichilioides Planch. & Simaroubaceae & 0.32 & 0.32 & 0.02 & 0.22 & 0.13 \\
\hline Cassia fastuosa Benth. & Fabaceae & 0.32 & 0.32 & 0.03 & 0.09 & 0.12 \\
\hline Eriotheca globosa (Aubl.) A. Robyns & Malvaceae & 0.32 & 0.32 & 0.03 & 0.01 & 0.12 \\
\hline Bellucia dichotoma Cogn. & Melastomataceae & 0.32 & 0.32 & 0.01 & 0.22 & 0.12 \\
\hline Ambelania acida Aubl. & Apocynaceae & 0.32 & 0.32 & 0.01 & 0.22 & 0.11 \\
\hline Rudgea cornifolia (Kunth) Standl. & Rubiaceae & 0.32 & 0.32 & 0.00 & 0.22 & 0.11 \\
\hline Miconia ruficalyx Gleason & Melastomataceae & 0.32 & 0.32 & 0.00 & 0.22 & 0.11 \\
\hline Guatteria poeppigiana Mart. & Annonaceae & 0.32 & 0.32 & 0.00 & 0.09 & 0.09 \\
\hline Sum & - & 175.86 & 331.82 & 16.10 & 181.50 & 100 \\
\hline
\end{tabular}

AF: absolute frequency, AD: absolute density $\left(\mathrm{n} \mathrm{ha}^{-1}\right)$, ADo: absolute dominance $\left(\mathrm{m}^{2} \mathrm{ha}^{-1}\right)$, ASP: absolute sociological position, EIV: expanded importance value (\%). 
(127), Sapotaceae (86), Burseraceae (63), Humiriaceae (55) and Chrysobalanaceae (44), accounting a $79.4 \%$ of total individuals sampled. Regarding species diversity, the families that contributed the most were Fabaceae (17 species), Chrysobalanaceae (4), Myrtaceae (3), Rubiaceae (3), Anacardiaceae (2) and Annonaceae (2). These six families represent $48.4 \%$ of total species. The other 26 families, including one of the species identified at the gender level, totalize $51.6 \%$ of the total species.

The Shannon-Weaver diversity index $\left(H^{\prime}\right)$ found in this study was 3.03, and the estimated level of Pielou's evenness $(J)$ recorded was 0.73 . The denser species $(\mathrm{AD} \geq 9.0$ individuals ha ${ }^{-1}$ ), in descending order, were Campsiandra laurifolia, Glicoxylon pedicellatum, Hevea brasiliensis, Tetragastris altissima, Mabea caudata, Vantanea parviflora and Inga capitata, which together represent $65.7 \%$ of the absolute density. However, it was observed that 30 species are "locally rare", that is, less than one tree per hectare.

Among the densest species that had the highest absolute frequencies (AF), stand out: Hevea brasiliensis, Tetragastris altissima, Campsiandra laurifolia, Vantanea parviflora, Mabea caudata and Glicoxylon pedicellatum, representing over $45 \%$ of the sample units. The species with the highest absolute dominance (ADo $\geq 0.50 \mathrm{~m}^{2} \mathrm{ha}^{-1}$ ) were Hevea brasiliensis, Campsiandra laurifolia, Glicoxylon pedicellatum, Inga capitata, Tetragastris altissima, Vataireopsis speciosa, Vantanea parviflora, Inga auristellae and Nectandra sp., which together represent $61.2 \%$ of the total dominance.

The stratification achieved by means of multivariate techniques showed that the community is composed of three main groups of height classes, according to conventional total height strata; the average height was equivalent to 10 $\mathrm{m}$. The classification of individual trees in a range of $1 \mathrm{~m}$ allowed a sequential grouping of the total height classes in three strata: low, medium and high (figure 1). Figure 1 demonstrates that the results obtained by means of multivariate techniques corroborate the actual data field, suggesting an efficiency in the use of these techniques for the definition of the strata and, allowing a more coherent discussion on the behavior of the species in the community.

A discriminant analysis already showed that $100 \%$ of height classes were properly classified in the strata defined by the cluster analysis. The low stratum $\left(\mathrm{H}_{\mathrm{T}} \leq 11 \mathrm{~m}\right)$ presented 703 individuals, being the Campsiandra laurifolia the most representative species of this stratum (figure 1). The medium stratum $\left(12 \mathrm{~m} \leq \mathrm{H}_{\mathrm{T}} \leq 19 \mathrm{~m}\right)$ registered 274 individuals, of which Hevea brasiliensis and Glicoxylon pedicellatum were the most abundant in this stratum. The high stratum covered trees with heights above $20 \mathrm{~m}$ $\left(\mathrm{H}_{\mathrm{T}} \geq 20 \mathrm{~m}\right)$, totalizing 45 individuals. In this stratum the most abundant species was the Hevea brasiliensis.

The most common species of the forest in all strata that obtained the highest ASP values were: Campsiandra laurifolia, Glicoxylon pedicellatum, Mabea caudata, Tetragas-

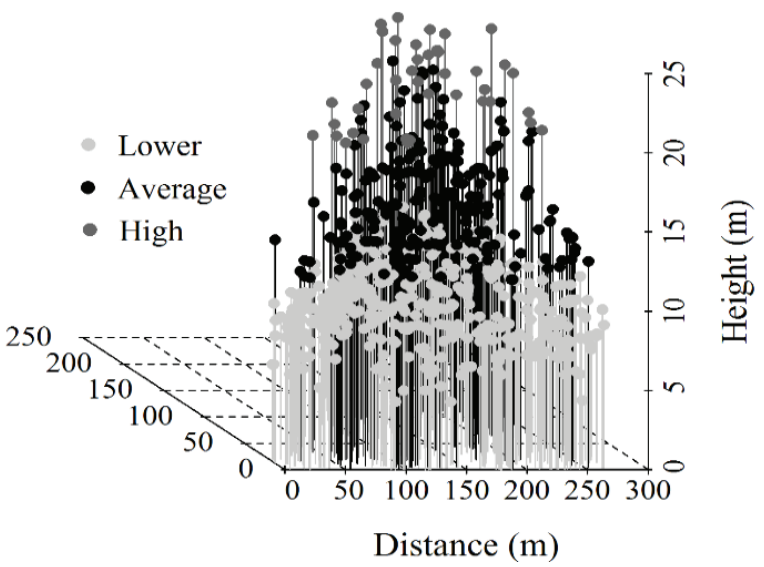

Figure 1. Total height strata of a natural fragment of the floodplain forest on the banks of the Tapajos River, State of Pará, Brazil.

Estratos de altura total de un fragmento natural de bosque inundable en las orillas del río Tapajós, estado de Pará, Brasil.

tris altissima, parviflora Vantanea and Hevea brasiliensis, which together represent $54.7 \%$ of the total amount of the studied selection. Regarding the ecological importance of the species in the community, defined by the expanded importance value index, the seven highest values were achieved by Campsiandra laurifolia, Hevea brasiliensis, Glicoxylon pedicellatum, Tetragastris altissima, Vantanea parviflora, Mabea caudata and Inga capitata.

Diametric distribution. The distribution curve of the individuals considering the community follows the typical pattern of uneven-aged tropical forests, expresses an exponential distribution in the form of an inverted J, with a predominance of $83.6 \%$ of the individuals sampled in the first two diameters (figure 2). However, this analysis referred to the community may not be sufficient to evaluate the conditions of arboreal component, requiring an evaluation of the populations to allow more accurate detection standards regarding the forest structure. The diametric structure of six of the seven species of superior ecological importance showed a similar community distribution, having a larger presence of individuals in the first diameter classes.

The species Campsiandra laurifolia, Mabea caudata, Vantanea parviflora, Glicoxylon pedicellatum and Tetragastris altissima prevailed in the first two diameter classes, therefore more than $82 \%$ of tree individuals showed DBH in the range of 10 to $30 \mathrm{~cm}$, while Inga capitata presented a better distribution in the diameter classes larger than $30 \mathrm{~cm}$, likewise at lower density. Furthermore, a discontinuity of the distribution was detected in more than one diameter class, and in the successive classes for these species.

The distribution pattern of individuals in diameter classes was not recurrent in all species with big ecological importance. The Hevea brasiliensis species was the only one 

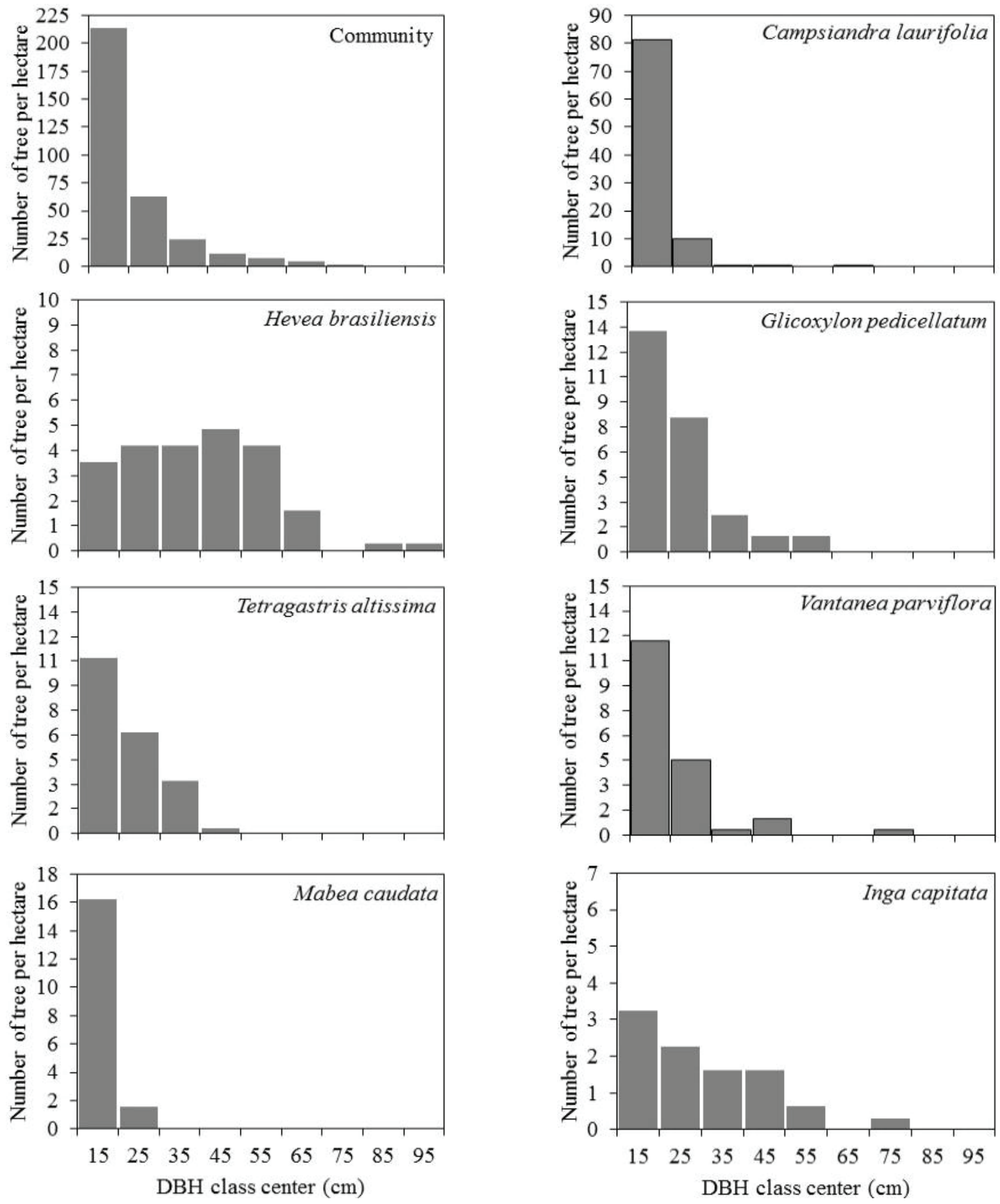

Figure 2. Diametric distribution of the community and species of high ecological value in a natural fragment of the floodplain forest on the banks of the Tapajos River, State of Pará, Brazil.

Distribución diamétrica de la comunidad y de las especies de mayor importancia ecológica en un fragmento natural de bosque inundable en las orillas del río Tapajós, estado de Pará, Brasil. 
that did not have a negative exponential tendency, presenting a lower amount of trees in the first two diameter classes and a larger number of individuals in the intermediate classes $(30 \mathrm{~cm} \leq d b h<70 \mathrm{~cm})$.
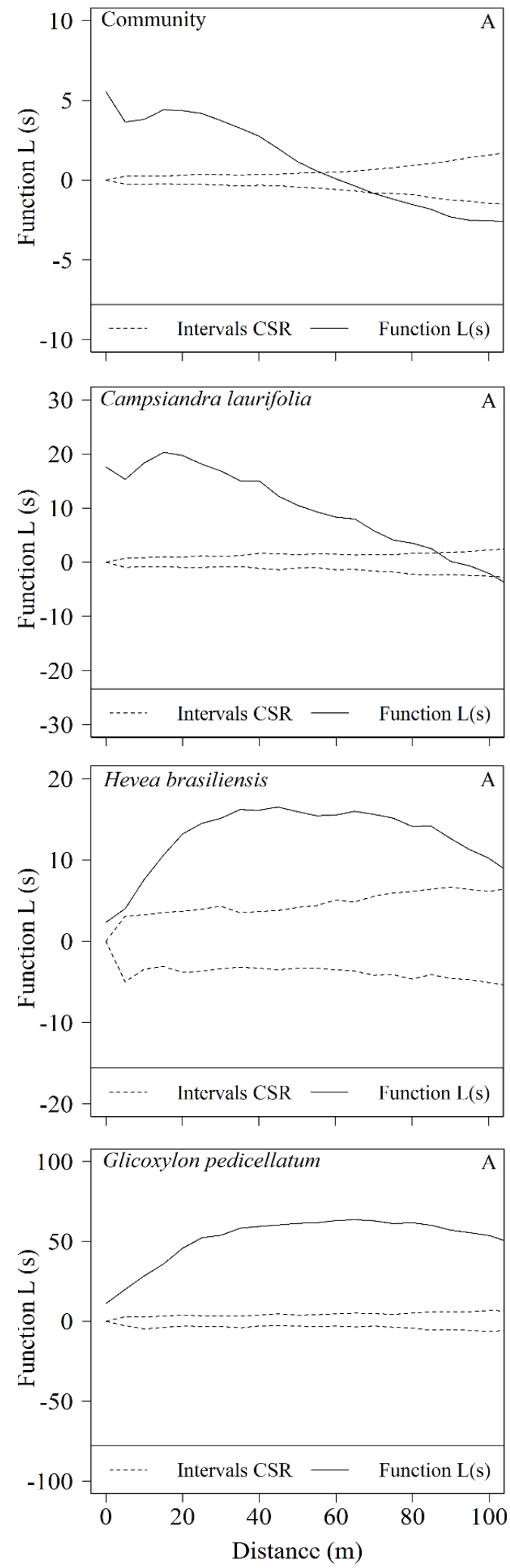

Spatial pattern. The community has a predominantly aggregated spatial distribution pattern (figure 3A). In that case, the hypothesis of complete spatial randomness (CSR) is rejected for the community. For the species of
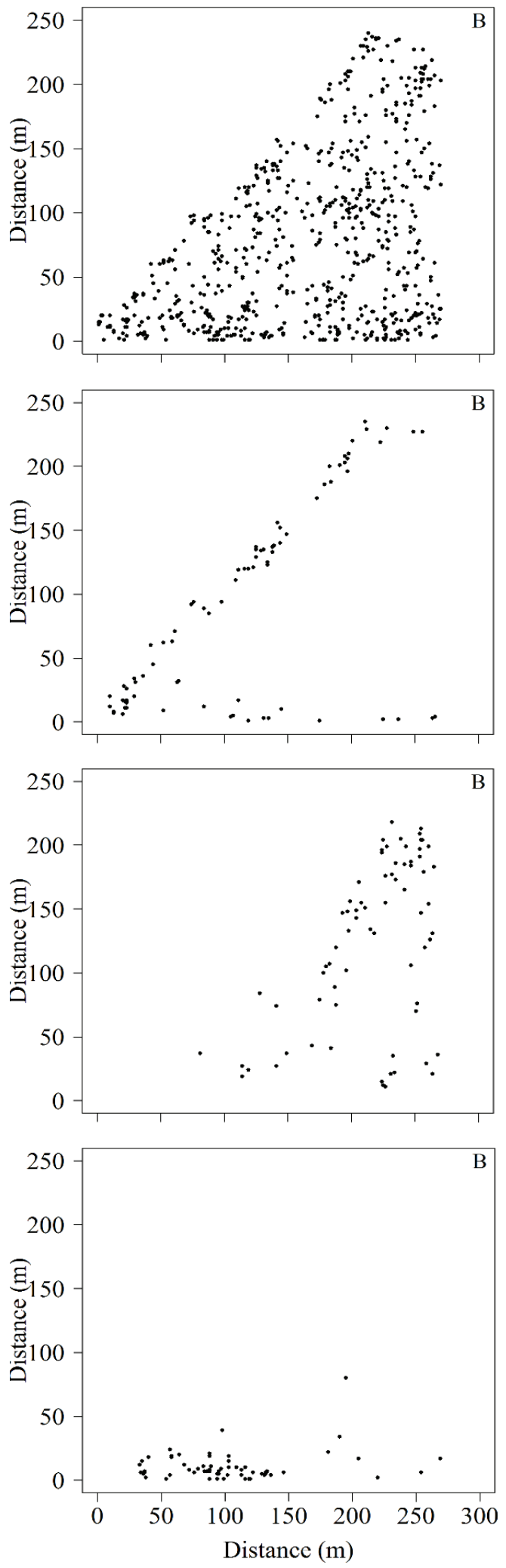

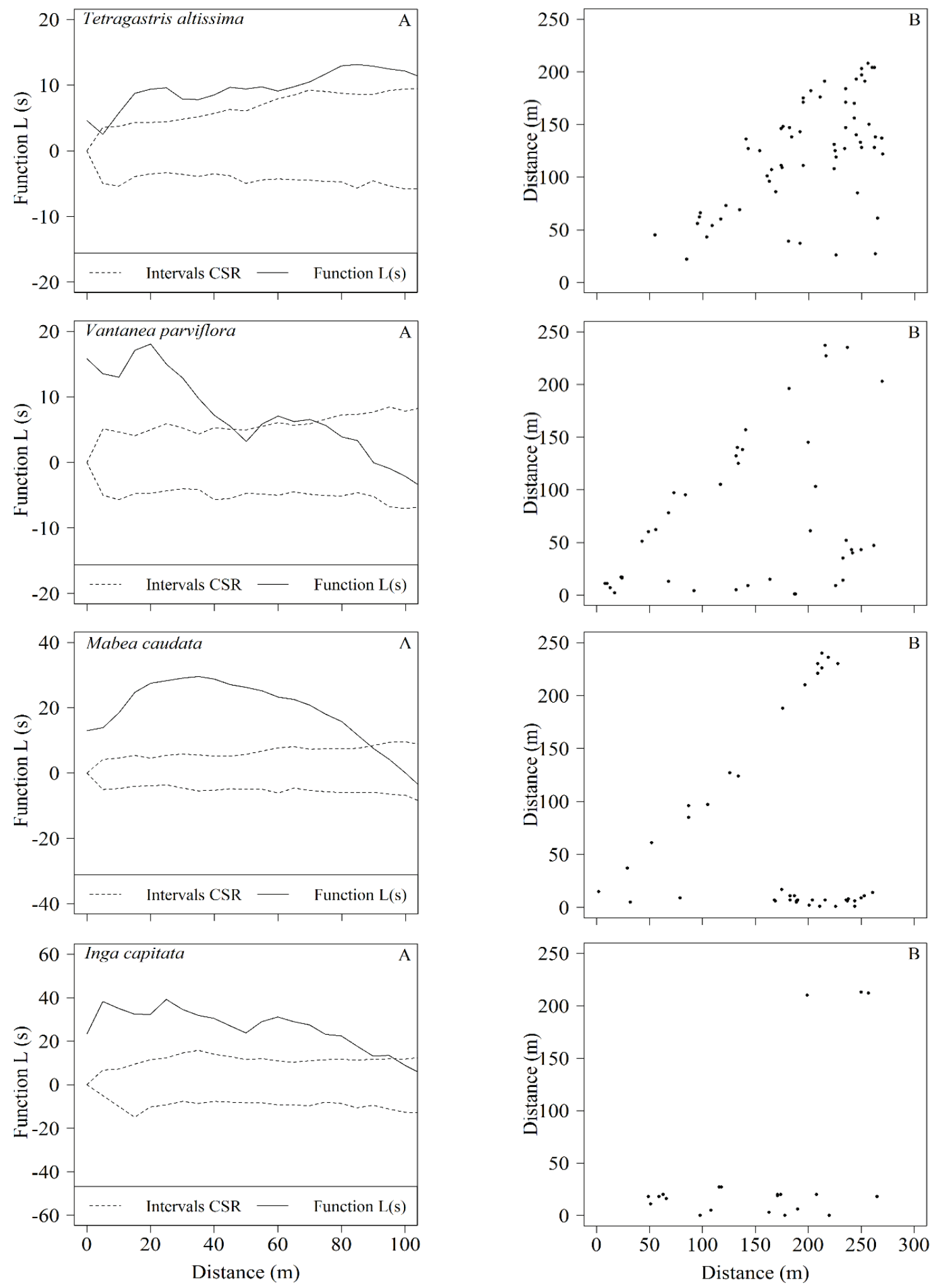

Figure 3. Spatial pattern $[A]$ and distribution of trees $[B]$ in the community and major species $[B]$ in a natural fragment of floodplain forest on the Amazonian Peace Island, State of Para.

Patrón espacial y mapa de distribución de la comunidad y las principales especies arbóreas en un fragmento de bosque natural inundable en la isla de la Paz Amazónica, estado de Pará. 
high ecological value, the confidence graphic scale showed that CSR hypothesis was also rejected, consequently at a certain point of the distance scale there was some degree of aggregation, regularity or both. It was also observed, through the distribution maps, that these species, except for Tetragastris altissima and Hevea brasiliensis, were mainly present near the shores of the island. The analysis of figures $3 \mathrm{~B}$ corroborates these assertions, because the points represent the trees that are generally distributed on the shores of the island. The contour formed by the points of the species Campsiandra laurifolia perfectly demonstrate the margin of the island.

For the species Campsiandra laurifolia and Mabea caudata the function $L(s)$ remained above the upper limit of the confidence graphic scale (confidence envelope) with $85 \mathrm{~m}$, showing an aggregated pattern, but after this distance function $L(s)$ the CSR region is introduced, indicating randomness of individuals. Hevea brasiliensis, Glicoxylon pedicellatum and Inga capitata had a completely aggregated spatial pattern, while Tetragastris altissima presented a degree of aggregation for distances shorter than $5 \mathrm{~m}$, reaching a partially aggregated and random spatial pattern up to $10 \mathrm{~m}$, approximately, from which individuals return to an aggregated pattern and remain with it up to $110 \mathrm{~m}$. Vantanea parviflora had the lowest estimation on the function $L(s)$ with values close to each other, which contributed to an oscillation between aggregated and random patterns at different distance scales.

\section{DISCUSSION}

The relation of the number of families, genera and species of this study is similar to other surveys conducted in the Amazonian floodplain forests areas (Ferreira 1997, Parolin et al. 2004, Ferreira et al. 2010, Hamaguchi and Scudeller 2011). Considering floristic surveys in non-floodplain forests (Almeida et al. 2012, Ribeiro et al. 2013), it was found, in general, a superior number of species. According to Hamaguchi and Scudeller (2011), this reduction in the number of species is caused by characteristics of the environment, that is, soils with high levels of saturation during flood periods, resulting in a negative relationship between soil moisture and species prosperity. This relationship is even more evident when analyzing gradients of soil drainage, as noted by Cattanio et al. (2002) in a floodplain forest of the Amazon estuary, where lower places with poor drainage and low levels of oxygen for long periods were less rich, with an ecological dominance of the surrounding typical species.

Among the botanical families found, the Fabaceae was the most significant in wealth (17 species) and abundance (437 individuals) corroborating the studies by Ferreira and Prance (1998) and Parolin et al. (2004) in other Amazonian floodplain forests. Among the 17 species of the Fabaceae family, ten belong exclusively to mainland and they have a low general abundance, while only seven are presented as unique species of wetland environments, of which four of them are abundant. This behavior suggests that the propagules sources are influencing more species that are present at lower densities, which are the habitat general species. According to Marques et al. (2003), general species from drained soils increase the prosperity of floodplain forests, since species adapted to water excess, usually few, are important in defining the community dominance and density, which explains the fact that the studied area presents a high dominance and density of Campsiandra laurifolia.

It was observed that the area has a low floristic diversity, as the value of the Shannon-Weaver index for tropical forests normally varies from 3.83 to 5.85 (Knight 1975). However, when compared with the results presented by Ferreira (1997) $\left(H_{1}^{\prime}=1.63, H_{2}^{\prime}=3.00 \mathrm{e} H_{3}^{\prime}=3.3\right)$ and Hamaguchi and Scudeller $(2011)\left(H^{\prime}=2.29\right)$, diversity was considered high and equivalent, which indicates that diversity of species, when compared to other areas within the same phyto-physiognomy, is compatible with other floodplains in the Amazon. At the same time, the Pielou's evenness index $(J=0.73)$ suggested that the plant community has moderately high flora heterogeneity. Salomão et al. (2007) analyzed a similar forest configuration in the river Xingu (PA), and found a value of 0.80 , while Vale et al. (2014) found values above 0.79 for six different floodplain forests in the hydrographic subbasin of the river Peixe-Boi (PA).

The low diversity values found in this study are the result of the abundance of few species, such as Campsiandra laurifolia, Glicoxylon pedicellatum, Hevea brasiliensis and Tetragastris altissima, which together represent $48.8 \%$ of all individuals, and of environmental variations caused by annual flood periods in the Tapajós River, along with the visible rising rates of erosion and sedimentation on the island. However, the small amount of dominant species simplifies the process of choosing species for the floodplain forest restoration, since there are few species with high ecological value.

When the analysis of phytosociological parameters was performed, it was observed that Campsiandra laurifolia, Hevea brasiliensis, Glicoxylon pedicellatum, Tetragastris altissima, Vantanea parviflora, Mabea caudata and Inga capitata stood out for their high ecological value, due to the combination of frequency, dominance and density with which they were found in the plots. These results corroborated those found by Ferreira and Prance (1998) that mentioned the Campsiandra laurifolia, Mabea caudata and Tetragastris altissima as important species and stated characteristics of flood-prone areas, therefore they can be recommended for wetlands restoration and flooded riparian areas in the Tapajós River basin. It is worth noting that Campsiandra laurifolia has herbal phytotherapy uses in many of the Amazon rural communities, mainly treating wounds, bruises, malaria and ulcer (Chagas et al. 2010). According to Chagas et al. (2010), maroons from Arancuã community in the state of western Pará, use the infusion of the leaves, decoction of the bark and tapioca fruit (star- 
chy part obtained from aqueous maceration and drying in sunlight exposure) for cutaneous leishmaniasis treatment.

Although Campsiandra laurifolia is predominant, there was abundant presence of mainland general and unique species, such as Hevea brasiliensis, Vantanea parviflora, Glicoxylon pedicellatum, Tetragastris altissima and Inga capitata. According to Kubitzki and Ziburski (1994), the origin of many of these species is related to floristic composition of the mainland adjacent areas, while Wittmann et al. (2006) relate this behavior to probable periods of relatively small flood levels, which would have favored the establishment of these tree species in flooded environments whose soils are more fertile due to the influence of the many nutrients the river carries. Subsequently, these species have colonized floodplain areas and some have developed their own adaptations to periodic flooding. The historical sequence of the National Water Agency shows that in the years 1970-2002 the flood levels in the Tapajós River were below average, during which the higher areas of the island would have been provided with the necessary soil conditions for the establishment of these species. Since 2003 there has been a continuous increase in flood levels, registering in 2009 a historical milestone of $8.32 \mathrm{~m}$.

The ecological importance of Hevea brasiliensis seems to reflect the historical influence of these low flood levels and of the adjacent floristic composition, as there are native rubber plantations surrounding the island. However, it is noted that the selection of this species for restoration purposes in flood-prone areas should be cautious, since locations with excessive humidity are less suitable for planting this species, because it offers the ideal conditions for the activation of diseases, which limits the growth of smaller individuals, as noted in the diametric structure of the species. By virtue of the root system development, it is recommended that the planting of this species should be in medium textured soils with good depth, avoiding floodprone areas, clayey and poorly drained.

Generally, the diameter distribution analysis allows us to infer the forests demographic status and their possible conservation problems. At first, the diametric distribution in the inverted $\mathrm{J}$, showed a high concentration of individuals in the smaller diameter classes, possibly corresponding to younger trees, and therefore ensuring the communities prosperity and regeneration. Other studies conducted in floodplains by Parolin et al. (2004) and Salomão et al. (2007) demonstrated a similar behavior to that found in this study. Nevertheless, the high concentration of individuals in the first diametric classes is the result of the abundance of Campsiandra laurifolia and Mabea caudate, understory species that belong exclusively to floodplain areas that present low diameter values.

In general, the diameter distribution of the species of high ecological value is caused by the dynamics of mortality and birth of new individuals to the community, as a result of the falling trees in this location. Unstable soil increases the possibility of the falling of larger trees, and limits the growth of others, since, according to the root system, the reduced depth is not adequate to settle a tree, which ends up causing a large number of short stature individuals in the community. Connected to this, the constant falling of the largest trees allows the recruitment of previously established juvenile individuals, associated also with the good availability of water, nutrients and light available by falling trees, presenting a higher density.

The community and species of high ecological value present predominantly aggregated distribution patterns. According to Negrini et al. (2012), tropical forests have aggregated patterns especially given the dispersion syndrome and the presence of micro-sites favorable to the establishment of species that make up the community. Species with hydrochoric dispersal syndromes (Campsiandra laurifolia), autochoric (Mabea caudata and Hevea brasiliensis) and zoochoric (Glicoxylon pedicellatum, Inga capitata, Tetragastris altissima and Vantanea parvifora) favor an aggregated distribution in virtue of a limited distribution of propagules, since many of these species are preferably distributed in flooded areas (Negrini et al. 2012).

Among these species, Vantanea parviflora was the only one with variations in the spatial pattern at different distance scales, behavior that was also observed by Araújo et al. (2014) in individuals from Callisthene major Mart. These variations may be related to the size of the individual, since the younger individuals tend to appear closer to each other, forming aggregates. According to Araújo et al. (2014), there is an increasing competition as these individuals grow, and few reach the larger diameter being more distant from each other, causing random distribution.

From a quantitative point of view, the gathered knowledge about the spatial patterns of these species, in particular Campsiandra laurifolia, used also for medical purposes, facilitates the setting of the sampling systems that is applied on flood-prone environments, in order to estimate properly the species density. For populations that are distributed in an aggregated manner, density estimations becomes more complicated because of the difficulty of finding clusters by traditional sampling methods, which constitutes a random or even distribution of the sampling units. However, studies indicate that sampling procedures with a disposition of grouped plots, just as the clustered adaptive sampling, would probably have a better possibility of success in the estimation of these populations' parameters, since the grouped plots increased the chance of detecting individual's aggregates. Bruzinga et al. (2013) studied sampling methods applicable to aggregated populations, concluding that adaptive cluster sampling provides a higher precision in estimating the density parameter.

\section{CONCLUSIONS}

According to diversity and evenness indicators, the area presents a low diversity, although compatible with other floodplains, and a moderate concentration of species 
with high uniformity in the proportions individuals/species within the plant community.

For being abundant, dominant and always conditioned to the soil humidity, the use of Campsiandra laurifolia is recommended for the recovery of floodplain forests. The species with high ecological value presented a diametric distribution in the form of an inverted J, except for Hevea brasiliensis.

The community presented a predominantly aggregated spatial pattern, as the most important species followed, in general terms, the spatial pattern of the community, except Vantanea parviflora, which proved to be partially and aggregated and random.

\section{ACKNOWLEDGEMENTS}

The authors would like to thank the research funding agency CAPES for the scholarships granted to the postgraduate student participating in the study.

\section{REFERENCES}

Almeida LS, JRV Gama, AS Oliveira, JOP Carvalho, DCM Gonçalves, GC Araújo. 2012. Fitossociologia e uso múltiplo de espécies arbóreas em floresta manejada, Comunidade Santo Antônio, município de Santarém, Estado do Pará. Acta Amazonica 42(2): 185-194.

Angiosperm Phylogeny Group III. 2009. An update of the Angiosperm Phylogeny Group classification for the orders and families of flowering plants: APG III. Botanical Journal of the Linnean Society 161(2): 105-121.

Araújo EJG, HC David, N Péllico-Neto, VA Morais, JRS Scolforo. 2014. Padrão espacial de espécies arbóreas em fragmento de floresta estacional semidecidual. Ciências Agrárias 57(2): 166-171.

Brower JE, JH Zar, CN Ende. 1998. Field and laboratory methods for general ecology. Boston, U.S. McGraw-Hill. 273 p.

Bruzinga JS, MLR Oliveira, ELM Machado, HG Leite, IM Pereira, GS Nogueira. 2013. Distribuição espacial de individuos adultos de pequi. Scientia Forestalls 41(98): 249-256.

Cattanio JH, AB Anderson, MS Carvalho. 2002. Floristic composition and topographic variation in a tidal floodplain forest in the Amazon Estuary. Revista Brasileira de Botânica 25(4): 419-430.

Chagas AP, AD Muller, MBP Soares, LM Garcez. 2010. Potencial anti-Leishmanina e imunomodulador dos extratos de Campsiandra laurifolia Benth. (Fabaceae). Revista PanAmazônica de Saúde 1(1): 117-124.

Chaves CL, CS Manfredi. 2010. Arbóreas medicinais das matas ciliares do Rio Canoas: potenciais de uso em projetos de restauração. Revista Brasileira de Plantas Medicinais 12(3): 322-332.

Dias RM, NNB Salvador, MBC Branco. 2014. Identificação dos níveis de degradação de mata ripárias com o uso de SIG. Floresta e Ambiente 21(2): 150-161.

Ferreira LV. 1997. Effects of the duration of flooding on species richness and floristic composition in three hectares in the Jaú National Park in floodplain florest in Central Amazonia. Biodiversity and Conservation 6(10): 1353-1363.
Ferreira LV, GT Prance. 1998. Structure and species richness of lowdiversity floodplain forest on the Rio Tapajós, Eastern Amazonia, Brazil. Biodiversity and Conservation 7(5): 585-596.

Ferreira LV, SS Almeida, P Parolin. 2010. Amazonian white - and blackwater floodplain forests in Brazil: large differences on a small scale. Ecotropica 16(1): 31-41.

Freitas EP, JFL Moraes, A Peche Filho, M Storino. 2013. Indicadores ambientais para áreas de preservação permanente. Revista Brasileira de Engenharia Agrícola e Ambiental 17(4): 443-449.

Gomes FS, MLS Guedes, RM Valadão, ARS Prates, MAA Costa. 2014. Florística e estrutura de um trecho de mata ciliar do rio Carinhanha, Feita da Mata, Bahia, Brasil. Biotemas 27(3): 41-55.

Hamaguchi JO, VV Schudelller. 2011. Estrutura arbórea de uma floresta de igapó no lago Tupé, Manaus, AM. In Santos-Silva EM, VV Schudeller, MJ Calvacanti eds. Biotupé: Meio Físico, Diversidade Biológica, Sociocultural do Baixo Rio Negro, Amazônia Central. Manaus, Brazil. UEA. p. 83-97.

IBGE (Instituto Brasileiro de Geografia e Estatística, BR). 2012. Manual técnico da vegetação brasileira. Brasília, Brasil. IBGE. 271 p.

Knight DHA. 1975. Phytosociological analysis of species-rich tropical forest on Barro Colorado Island, Panama. Ecological Monographs 45(3): 259-284.

Kubitzki K, A Ziburski. 1994. Seed dispersal in flood plain forests of Amazonia. Biotropica 26(1): 30-43.

Marques MCM, SM Silva, A Salino. 2003. Florística e estrutura do componente arbustivo-arbóreo de uma floresta higrófila da bacia do rio Jacaré-Pepira, SP, Brasil. Acta Botanica Brasilica 17(4): 495-506.

Mueller-Dombois D, H Ellemberg. 1974. Aims and methods of vegetation ecology. New York, U.S. John Wiley \& Sons. $547 \mathrm{p}$.

Negrini M, MD Aguiar, CT Vieira, AC Silva, P Higuchi. 2012. Dispersão, distribuição espacial e estratificação vertical da comunidade arbórea em um fragmento florestal no planalto catarinense. Floresta 36(5): 919-929.

Parolin P, Adis J, IL Amaral, L Schmidt, MTF Piedade. 2004. Floristic study of an igapó floodplain Forest in Central Amazonia, Brazil (Tarumã-Mirim, Rio Negro). Amazoniana 18(1/2): 29-47.

Ripley BD. 1979. Tests of randomness for spatial point patterns. Journal of the Royal Statistic Society 41(3): 368-374.

Ribeiro RBS, JRV Gama, SV Martins, A Moraes, CAA Santos, AD Carvalho. 2013. Estrutura florestal em projeto de assentamento, comunidade São Mateus, município de Placas, Pará, Brasil. Ceres 60(5): 610-620.

Rodrigues RR, AG Nave. 2000. Heterogeneidade florística das matas ciliares. In Rodrigues RR, HF Leitão-Filho eds. Matas ciliares - Conservação e Recuperação. São Paulo, Brasil. Fapesp. p. 45-71.

Salomão RP, ICG Vieira, C Suemitsu, NA Rosa, SS Almeida, DD Amaral, MPM Menezes. 2007. As florestas de Belo Monte na grande curva do rio Xingu, Amazônia Oriental. Boletim do Museu Paraense Emilio Goeldi 2(3): 57-153.

Souza DR, AL Souza, JRV Gama, HG Leite. 2003. Emprego de análise multivariada para estratificação vertical de florestas inequiâneas. Árvore 27(1): 59-63.

Vale I, LGS Costa, IS Miranda. 2014. Espécies indicadoras para 
recomposição da floresta ciliar da sub-bacia do rio PeixeBoi, Pará. Ciência Florestal 24(3): 573-582.

Wittmann F, J Schongart, JC Montero, TMWJ Junk, MTF Pie- dade, HL Queiroz, M Worbes. 2006. Tree species composition and diversity gradients in white-water forests across the Amazon Basin. Journal of Biogeography 33(8): 1334-1347.

Recibido: 05.09.16

Aceptado: 18.04 .17 
